\title{
WDHA Syndrome
}

National Cancer Institute

\section{Source}

National Cancer Institute. WDHA Syndrome. NCI Thesaurus. Code C3488.

A rare syndrome characterized by severe watery diarrhea, hypokalemia, and achlorhydria.

It is caused by the oversecretion of vasoactive intestinal peptide from the pancreatic islet cells. 